\title{
ANALYSIS ON THE ROMANIAN BANKING LEGISLATION AND THE BANKS PROBABILITY OF DEFAULT
}

\author{
Associate Professor PhD Iulia Iuga, "1 Decembrie 1918” University of Alba Iulia, \\ iuga_iulia@yahoo.com
}

\begin{abstract}
This paper examining the perception on the judicial system and the law enforcement associated to the banks' probability to default. Credit institutions must continuously update and undertake a satisfactory legal analysis, which is to confirm the possibility of signing collateral contracts in all relevant jurisdictions. If necessary the analysis must be updated in order to assure, at any moment, the enforcing of those contracts.
\end{abstract}

Keywords: probability to default, legal analysis, collateral contracts, jurisdictions

JEL Codes: G21

The banking field of the countries in transition remarkably developed in the last 15 years. The bank activity from most countries in transition actually exceeded the specific trauma of transition. Therefore, the banks of these countries are very much alike those of anywhere else at the beginning of the $21^{\text {st }}$ century. A surprisingly great number of studies that provided information about bank performances were carried out, but not many things about their position about assuming risks and the way in which this is influenced by the bank environment are known. The institutional area of a country differs a lot from that of all the others. Berger and Udell (2002) [1.], Berger et al. (2001) [2.] and Haselmann and Wachtel (2006) [3.] proved that banks differently react according to the existing institutional regime. Berger and Udell (2002), for example, found out that banks are more willing to offer finance to debtors they do not hold insufficient information about into a better legal system.

That is to say, if reliable guarantee regulations do exist, the banks will grant credits to risky debtors even though they do not have sufficient information, such as, financial statement or statement of account. From this point of view, the improvement in the bank legislative area is associated to a high level of risk assumed by the banks. The bank activity of the countries in transition has rapidly got over four different stages (see Bonim and Wachtel 2003) [4.].

The first stage of bank development for the economies in transition meant the setting up of banking institutions at the beginning of the 90's. During the planned economy era - mostly unknown -, the only existing financial institutions were appendix for the state mechanism and bank activity, in the contemporary sense of the word. The commercial banks were separated from the payment central banking system. Anyway, the role of these institutions was mostly unchanged. The state banks financed state enterprises, quickly becoming insolvent.

The second stage of the banking transition process consisted of banking crashes and systemic crisis that affected in a negative way all economies in transition after 1990 (see Bonim and Wachtel 2005) [5.].

The third stage consisted of a long process of reorganisation by privatisation and the intermission of foreign banks. Most banks were private property and the foreign banks dominated the bank activity in the countries in transition at the end of the century.

The forth stage brings us to the present moment. In most economies in transition banks are safe, competitive and adequate regulated institutions. The bank activity from the period of transition left aside any kind of track from the period of the planned economy. The research made in the field 
of the transition economy is exhaustive and the problems about risk assuming and administration still remain with no kind of investigation. The first studies about the bank activity in the transition period were focused on the bank institutions creation and structure (see Corbet and Mayer 1992 [6.], Udell and Wachtel, 1995 [7.]). According as the transition process developed, the research interest focused on the bank performances and the bank activity efficiency later on.

Recent studies approached the bank crises, the processes of reorganization and privatization that marked the transition period. Haas and Lelyveld (2006) [8.] and Haselmann (2006) [9.] finally focused on the consequences the foreign banks intermission brought upon the bank sector stability. The studies concerning the risk management carried out by the banks in the economies in transition are rare because the information about specific bank activities is very limited. Schardax and Reininger (2001) [10.] investigate the vulnerability to the financial contagiousness of the finance systems of the transition economies at macro-economic level. Kager (2002) [11.] focuses especially on banks at individual level and pointed out that the non-performance credits problem persists in many banks having economies in transition, Romania included. In Haselman and Wachtel's work (2007) [12] the three following points resume their discovering:

1. Certain bank groups differ at the risk level; for example, the foreign banks from the European Union and the big ones disclose a less probable loss by comparison with their competitors. Still, they are not but slight differences that are generally statistically insignificant and this issue reveals the fact that the bank markets are relatively homogeneous and no groups of banks that can take excessive risks may be identified.

2. They did not find out a clear connection between the taking risk activity by the banks and their legislative environment. Their discovering still reveals the fact that the banks that carry out their activity in a less secure institutional area retain more capital and assume themselves less credit risk.

3. The banks that take more risks administrate them by the setting up, for example, of different risk administration departments or obtaining information about the borrowers. These banks also have the tendency to retain more capital.

Nevertheless, banks adapt themselves to the area in which they operate by adapting their own capital. Haselmann and Wachtel (2007) [12.] pointed out that the differences at the legal environment level alter the credit portfolio composition. The banks do not have comprehensive information at their disposal when they engage themselves in a crediting process because the debtors are aware of the risk of their investment project.

There are still some stipulations may be included by the banks in their credit contracts for combating with the lack of information. Bester (1985) [13.] pointed out that the pledge may serve as warning instruments, taking into account the fact that the true risk degree is revealed by the guarantee size that the debtors are willing to produce. A good legislation to regulate the system of pledge and appropriate institutions to apply it are necessary for efficient warning instruments such the guarantee to exist. A growing reliability of the law and the agreements concerning the guarantee system may lead to the development of the guarantee employment for combating with the insufficiency of information and the generalised risk reduction. A debtor may use the same goods as pledge for different credit contracts or decline its handing in case of debt redemption impossibility in a poor regulated environment.

A more developed institutional environment is associated with a greater availability to use the guaranteed credits and an intense credit activity in this respect. This is accordingly with the data from the juridical and financial literature that indicates a positive connection between the rights of the creditors and the credit market development. (La Porta, et al., 1997, 1998). [14], [15.].

In Romania, a new package of normative documents in the domain of bank capital adequacy (The Government's Urgency Decree no. 99/2006 regarding credit institutions and capital adequacy, subsequently approved, in 2007, by the Law no. 227; The Order no.12/2007 of the National Bank of Romania regarding the reference of the minimal capital requirements to credit institutions; The 
Regulation of the National Bank of Romania and CNVM no. 22/27/2006 regarding the credit institution and investment firms capital adequacy; the Regulation of the National Bank of Romania and CNVM no. 18/23/2006 regarding private funds of credit institutions and investment firms; the Regulation of the National Bank of Romania and CNVM no. 13/18/2006 regarding the fixation of capital requirements for credit institutions and investment firms) was adopted in the context of the preliminary training of the Romanian banking system for the process of implementation of the Basel II Agreement stipulations in Romania.

The concept of capital adequacy is therefore present in our country, too, but in the first years of development of the Romanian banking system, the specific legislation made references to the capital requirements only (art. 40-43 of the Banking Law no. 58/1998) and the same concept was taken over by the national regulations (eg. the Government's Urgency Decree no. 99/2006 regarding credit institutions and capital adequacy) only when the Basel II Agreement has been implemented. The reference formula elaborated by the Bank Supervisors Committee from CEBS Europe that represent instruments necessary for bank supervising according to Basel II have been taken over and adapted for the Romanian banking system. It is about the Common solvency ratio REPorting framework that we are talking about. They were transposed at the individual level and consolidated through the Order of The National Bank of Romania no. 12/2007 regarding the reference of the capital minimal requirements for credit institutions and the FINancial REPorting stipulations that were transposed at individual level and consolidated by the Orders of the National Bank of Romania no.6/2007 and 13/2007 regarding the financial situation of credit institutions according to The International Standards of Financial Report. The references of the COREP type that commercial banks carry out at the National Bank of Romania stipulate the transmission of information that certifies if the credit institutions do respect the prudential requirements regarding the proper funds and capital requirements, credit risk, market risk and the operational one at individual level as well as the consolidated one. The references of the FINREP type represent an important intermediary between the bookkeeping information and the prudential one as well as an instrument used by the supervisors for checking the prudential information.

The national legislation according to the Basel Agreement II suggests two alternatives concerning the credit risk evaluation: - the standard method, according to which the capital requirements are calculated having in view the debtor's type and rating and allows the possibility of determining the credit quality also by using the evaluations made by institutions of credit external evaluation, - the internal models, having two possibilities: basic and advanced internal models that give to the bank the possibility for risk evaluation according to the specific features of each disposal. The risk weight and the capital that is due to it are determined by quantitative entrance combinations provided by credit institutions and formula specified in the Agreement based on modern risk management techniques that involve statistic evaluations. The national legislation according to the Basel II Agreement suggests two measurement alternatives of the interest rate risk, the share price risk, the currency circulation risk, the wares price risk and the transaction of options risk for market risk evaluation: - the standard method monitories these components of the market risk applying weights upon the positions in the transactional portfolio that is held for determining the losses in and extra balance positions owing to the inauspicious fluctuations of the market prices. - the internal methods permit us to fix the market risk by using the VAR Calue at Risk models on the basis of a set of quantitative and qualitative criteria and stress testing rigorous programmes.

The national legislation according to the Basel II Agreement suggests three measurement alternatives for operational risk evaluation: - the basis indicator approach, in which a single risk indicator of $15 \%$ is used at the level of a bank in order to calculate the capital requirements on the basis of a fix percentage of $15 \%$ from the annual average income registered in the last three years. the standard approach that implies the grouping of the bank activities into eight groups and the proper funds requirement is determined separately for each category by applying a specific coefficient between 12-18\% upon the gross proceeds from the last three years. - the advanced 
evaluation approach, where the capital requirements are calculated on the basis of the internal data of the banks regarding the operational loss through methodologies, as well as those of income volatility, those based on assets evaluation, parametrical models etc.

The European Commission adopted the THE WHITE BOOK regarding the European Union mortgage credit market integration on the $18^{\text {th }}$ of December 2007 . The following situation is presented in the document: the financial services providers may offer Trans- frontier mortgage credits in different ways: by their local presence (e.g. branches, subsidiaries, fusions and acquisitions); direct distribution channels (e.g.: by phone or internet); or local intermediaries (e.g. brokers).

The financial services providers may also engage into trans-frontier activities through mortgage portfolios acquisition from a mortgage creditor from a different state member. The differences of juridical order, the existence of fragmentised structures ( for example, credit registers), as well as the lack of an appropriate juridical framework in certain aspects (for example, for mortgage financing) creates juridical and economic obstacles that restrict the trans-frontier loans and hinder the development of the pan-European strategies capable of financing.

That is why the European Commission tries to eliminate the disproportioned obstacles in order to reduce the sale cost of mortgage products in the European Union.

\section{THE ANALYSE OF THE ROMANIAN CREDITING ACTIVITY VERSUS WORLD CRISES}

\section{In the sector of non-financial companies:}

The lending standards have become more restrictive. The expectations for the fourth trimester of 2008 are related to the tightening of the standards (especially for long term credits). Small and medium-sized enterprises (SME) have recorded a more accentuated tightening in the lending standards than for large companies, which is a trend seen since the second trimester of 2008.

In the opinion of the banks, the factors which contributed to this situation are:

1. the expectations regarding the general economic situation

2. the risk associated to the requested collateral/guarantee

3. the risk associated to the industry in which the company activates

4. the decisions of the National Bank of Romania (BNR) regarding the monetary policy

The crediting terms have maintained their trend in the last trimesters, on the lines of tightening the process.

- The risk associated to the requested collateral/guarantee is underlined as a factor with high influence over the standards and the crediting terms.

- $\quad$ The credits' demand has slackened in the third trimester of 2008.

- The risks associated to companies are perceived as increasing, including in the case of corporations. These evolutions are correlated with the ones recorded in the Euro area, where the negative perception over the lending risk has started since last year.

The competition level (both internal, in the banking sector and external, in the non-banking sector) has not determined changes in the crediting standards of companies. For the first trimester of 2009, the expectations are related to the tightening of the standards (especially for long term credits).

The general trend of tightening the terms of lending contracts (manifested in the last three semesters) has continued also in the fourth trimester of 2008:

(i) the requirements of collaterals/guarantees have been considerably revised in the last two trimesters, on the lines of an increased caution; 
(ii) the crediting costs, except the costs involved with interests, have grown to a larger extend in comparison to the previous trimesters;

(iii) the requested bonus for riskier credits has increased;

(iv) the spread of the medium rate of interest of the credit towards ROBOR $1 \mathrm{M}$ has increased;

(v) the maximum limit for the credit's value has dropped;

(vi) the contractual clauses have become more restrictive;

(vii) the maximum expiration for giving credits has been reduced.

\section{The population sector:}

- The lending standards have tightened for the consumer loans in the fourth trimester of 2008. The expectations for the first trimester of 2009 signal a potential strong tightening for all types of credits.

The net request for mortgage credits and consumer loans with mortgage have recorded a slight drop in the forth trimester of 2008, according to expectations.

\section{CONCLUSION}

The actual regulatory system does not satisfactorily address risks in the banking sector. The ongoing financial crisis has highlighted many weaknesses in the financial markets structures. One of the most important problems is related to the use of credit ratings in banking regulation. Moreover, risk management practices need to be improved in the future. The withdrawal of the ratings-based banking regulation will most likely not prevent future financial crises. Nevertheless, the negative consequences of these crises would be reduced in a significant way if the ratings-based regulation were replaced by more appropriate policies.

The objective of a revision is to give to banks the right incentives while choosing their investments. Bank capital regulatory schemes should for instance foster the building of reserves during economic booms and enable the banks to overcome an economic downturn. This could reverse some negative trends observed over the last decades, thereby serving the purpose of financial stability. The credit rating industry would work better as an information intermediary without the regulatory use of its credit ratings.

The banks would develop more appropriate means to assess the riskiness of their assets and might be wary of taking certain excessive risks.

\section{References:}

1. Berger, AN and Udell, GF. (2002): Small business credit availability and relationship lending: The importance of bank organizational structure. Economic Journal 112(477)

2. Berger, AN, Klapper, LF and Udell, GF. (2001): The ability of banks to lend to informationally opaque small businesses. Journal of Banking \& Finance 25(12): $2127-$ 2167.

3. Haselmann, R and Wachtel, P. (2006): Institutions and bank behavior. New York University, Stern School of Business, Working Paper EC06-16

4. Bonin, J and Wachtel, P. (2003): Financial sector development in transition economies: Lessons from the first decade. Financial Markets Institutions and Instruments 12: 1-66

5. Bonin, J and Wachtel, P. (2005): Dealing with financial fragility in transition economies. In: Evanoff, D and Kaufman, G. (eds). Systemic Financial Crises: Resolving Large Bank Insolvencies. World Scientific Publishing Company: Hackensack, NJ, USA. 
6. Corbet, J and Mayer, C. (1992): Financial reforms in eastern Europe: Progress with the wrong model. Oxford Review of Economic Policy 7(4): 5-75

7. Udell, G and Wachtel, P. (1995): Financial system design for the formerly planned economies: Defining the issues. Financial Markets Institutions and Instruments 4(2): 1-59.

8. Haas, R and van Lelyveld, I. (2006): Foreign banks and credit stability in central and eastern Europe: A panel data analysis. Journal of Banking and Finance 30: 1927-1952.

9. Haselmann, R. (2006): Strategies of foreign banks in transition economies. Emerging Market Review 7: 283-299.

10. Schardax, F and Reininger, T. (2001): The financial sector in five central and eastern European Countries: An overview. Focus on Transition 1/2001 Austrian Central Bank: Vienna.

11. Kager, M. (2002): The banking system in the accession countries on the eve of EU entry. Austrian Central Bank, Working Paper.

12. Haselmann, R., Wachtel P. (2006): Risk taking by banks in the transition countries. Comparative Economic Studies 49/2007.

13. Bester, H. (1985): Screening vs. rationing in credit markets with imperfect information. American Economic Review 75(4): 850-855

14. La Porta, R, Lopez-de-Silanes, F, Shleifer, A and Vishny, R. (1997): Legal determinants of external finance. Journal of Finance 52: 1131-1150.

15. La Porta, R, Lopez-de-Silanes, F, Shleifer, A and Vishny, R. (1998): Law and finance. Journal of Political Economy 106(6): 1113-1155.

16. Deaconescu D., (2005), Abordarea riscului operational conform noului Acord de la Basel, Revista Economie teoretica si aplicata, nr. 439

17. Opritescu M., Spulbar C., Nanu R., Opritescu A., Berceanu O. (2006), Tratat de management a riscurilor bancare, Editura Universitaria, Craiova

18. Rolf $\mathrm{H}$ Weber and Aline Darbellay, The regulatory use of credit ratings in bank capital requirement regulations, Journal of Banking Regulation (2008) 10, 1-16. doi:10.1057/jbr.2008.22

19. Romanian National Bank, Sondaj privind creditarea companiilor nefinanciare şi a populației, noiembrie 2008 